\title{
Step-Headache: A Distinct Symptom of Migraine
}

\author{
Sunil Pradhan ${ }^{1}$ Animesh Das ${ }^{1}$ Jayashri Ghosh ${ }^{2}$ \\ ${ }^{1}$ Department of Neurology, Sanjay Gandhi Postgraduate Institute of \\ Medical Sciences, Lucknow, Uttar Pradesh, India \\ 2Department of Medical Genetics, Sanjay Gandhi Postgraduate \\ Institute of Medical Sciences, Lucknow, Uttar Pradesh, India \\ J Neurosci Rural Pract 2020;11:89-94
}

\begin{abstract}
Address for correspondence Sunil Pradhan, DM, Department of Neurology, Sanjay Gandhi Postgraduate Institute of Medical Sciences, Raebareli Road, Lucknow 226014, Uttar Pradesh, India (e-mail: drspradhan@rediffmail.com).
\end{abstract}

\begin{abstract}
Keywords

- migraine

- primary headache

- headache

- step-headache

- throbbing

Objectives The diagnosis of migraine depends on various characteristics of headache with their associated constitutional symptoms such as nausea, vomiting, photophobia, and phonophobia. Relatively severe intensity, throbbing character, unilaterality, and aggravation with physical activity are the key features of migraine headache. We did this study to describe a new symptom (step-headache) in migraine in which some patients complained of uncomfortable or painful thump over the head with each footstep during walking or running.

Materials and Methods Self-designed proforma was filled in each clinically diagnosed patient of migraine or tension-type headache in an outpatient clinic setting. The symptom designated here as step-headache was evaluated in 150 patients of migraine including 26 patients with overlapping headache and 244 patients of tension-type headache. Binary logistic regression was used for association analysis of step-headache with subgroups of migraine and with other migraine features.

Statistical Analysis Frequency distributions were expressed as numbers (percentages) or mean \pm standard deviation. Binary logistic regression was used for association analysis of step-headache with subgroups of migraine and with other migraine features.

Results Step-headache was experienced by 97 (64.67\%) migraine patients with nearly equal distribution among the two clinical subtypes (61.5\% for migraine with aura and $65.3 \%$ for migraine without aura) but with high prevalence among perimenopausal onset migraine. Of all the patients who had this symptom, $77.32 \%$ experienced it during all the migraine attacks. The step-headache was differentiable from throbs of migraine and their exacerbation during physical activity by its synchrony with footsteps and its presence during nonpulsatile headaches or nonheadache phases of migraine. Sensitivity of this symptom was $64.67 \%$ while specificity was $100 \%$.

Conclusion Among primary headaches, step-headache is a less well-known but common and distinct symptom of migraine. It has good sensitivity and high specificity for migraine.
\end{abstract}

\section{Introduction}

Migraine is a common primary headache syndrome affecting $5.61 \%$ to a maximum of $26.1 \%$ of the general population in various countries. ${ }^{1,2}$ Despite identification of migraine as among the world's top 10 leading causes of disability, ${ }^{3}$ it

DOI https://doi.org/

10.1055/s-0039-3400197

ISSN 0976-3147. remains under diagnosed and under treated. ${ }^{4}$ This is mainly due to paucity of specific symptoms in migraine; the diagnosis thus depends on the constellation of common constitutional symptoms and the sequence of events., ${ }^{5,6}$ Marked variation in symptoms from person to person and even from attack to attack within an individual makes the diagnosis 
even more complicated, especially when migraine headaches becomes chronic or when it occurs in children with duration not fulfilling those of typical migraine attacks. These facts warrant a need for further characterization of migraine symptoms and elucidation of any finer observation, which we have attempted in this clinical study. We analyzed the sensitivity, specificity, and associations of step/tread linked head thump in migraine and other types of headache.

\section{Materials and Methods}

This was a cross-sectional observational study done in a tertiary care institute of Northern India on patients of primary headache. Written informed consent was taken from all the patients before inclusion in the study. A total of 150 patients of migraine and 244 patients of tension-type headache were recruited from the neurology outpatient department of our institute. Diagnosis of migraine was made according to the criteria of the International Headache Society- 3 beta. ${ }^{6}$ The patients were recruited between June 2015 and June 2018. Only the subjects with age of onset less than 50 years and attack frequency of at least 1 per month for previous 3 months were included. On the other hand, patients with hypertension, chronic cardiac or pulmonary disease, acute or chronic infections of upper airway and bony/venous sinuses of the cranium, chronic autoimmune inflammatory conditions, fibromyalgia, and spondylotic disease of the cervical spine were excluded from this study. A general questionnaire for headache that was based on International Classification of Headache Disorders-3 beta guidelines was used for the diagnosis and classification of the migraine patients into migraine with and without aura. The trigger factors were also registered. Furthermore, the migraine patients were categorized to special groups based on the onset of migraine. The patients with age of onset less than 18 years were included in childhood subgroup in the study. Patients experiencing migraine as a secondary cause after head injury were grouped to post head injury group. The institutional ethical committee approved the study.

Author (third author) first interviewed all the subjects face to face for around 25 to 45 minutes that included filling-up of the headache proforma and detailed verbal account of migraine symptomatology. Whenever the specific symptom that is being reported here was observed, another author (first author) confirmed the same by getting the detailed spontaneous response of the patient and cross-questioning regarding this specific symptom. The patient was then seen and treated independently by another author (second author) who was unaware of the step-headache symptom. Patients of headache were included in the study when there was concurrence in the diagnosis of headache type by third and second authors.

\section{The Symptom}

Step-headache was a feeling of painful thump that got transmitted from foot to head after each impact of the foot on the ground during walking, running, or climbing stairs. This thump was always felt on the painful side of the head and in whole of the head whenever the migraine was bilateral. This was regarded as present only when it occurred during footfall where it had a clear association with each footstep and not felt during sitting or lying state (unlike typical migraine throb). This unique symptom was also taken as positive whenever it was experienced during the prodrome or postdrome phase of migraine.

\section{Statistical Analysis}

Frequency distributions were expressed as number (percentage) or mean \pm standard deviation. Binary logistic regression was used for association analysis of step-headache with subgroups of migraine and with other migraine features. It was done using Statistical Package for Social Sciences, version 23.0. Armonk, New York. A p-value less than 0.05 was considered as significant.

\section{Results}

Our study group comprised of 244 tension-type headache patients (aged 16-65 years, mean $36 \pm 13.42$ years; 178 females) and 150 patients of migraine (aged 9-59 years, mean $31 \pm 11.28$ years, 123 females). A gender-wise demographic profile of the migraine patients under study is shown in - Table 1. Twenty-six (17.3\%) migraine patients had overlapping headache features including chronic

Table 1 Demographic profile of migraine patients enrolled in the present study

\begin{tabular}{|c|c|c|c|c|c|c|c|}
\hline \multirow{2}{*}{$\begin{array}{l}\text { Criteria of } \\
\text { subgrouping } \\
\text { migraine } \\
\text { patients }\end{array}$} & \multirow{2}{*}{$\begin{array}{l}\text { Subgroups of } \\
\text { migraine patients }\end{array}$} & \multicolumn{2}{|r|}{ Total } & \multicolumn{2}{|r|}{ Females } & \multicolumn{2}{|r|}{ Males } \\
\hline & & $\begin{array}{l}\text { No. of } \\
\text { cases }\end{array}$ & Mean age \pm SD & $\begin{array}{l}\text { No. of } \\
\text { cases }\end{array}$ & Mean age \pm SD & $\begin{array}{l}\text { No. of } \\
\text { cases }\end{array}$ & Mean age $\pm S D$ \\
\hline \multirow[t]{2}{*}{ Clinical subtypes } & $\mathrm{MO}$ & 124 & $33.65 \pm 8.894$ & 107 & $31.63 \pm 10.682$ & 17 & $27.47 \pm 14.054$ \\
\hline & MA & 26 & $32.41 \pm 9.076$ & 16 & $34.31 \pm 11.217$ & 10 & $25.30 \pm 10.822$ \\
\hline \multirow{5}{*}{$\begin{array}{l}\text { Special groups } \\
\text { on the basis of } \\
\text { migraine onset }\end{array}$} & Adolescent onset & 96 & $33.43 \pm 8.891$ & 79 & $33.90 \pm 8.843$ & 17 & $31.24 \pm 9.052$ \\
\hline & Childhood & 25 & $15.52 \pm 3.164$ & 17 & $16.59 \pm 2.717$ & 8 & $13.25 \pm 2.964$ \\
\hline & Perimenopausal & 14 & $43.93 \pm 7.711$ & 14 & $43.93 \pm 7.711$ & - & - \\
\hline & Post head injury & 15 & $29.08 \pm 10.226$ & 13 & $29.18 \pm 8.424$ & 2 & $28.50 \pm 23.335$ \\
\hline & Total & 150 & $31.01 \pm 11.285$ & 123 & $31.98 \pm 10.745$ & 27 & $26.67 \pm 12.776$ \\
\hline
\end{tabular}

Abbreviations: MA, migraine with aura; MO, migraine without aura; SD, standard deviation. 
tension-type headache (19), hypertension (2), short sharp headache (2), cluster (2), and sinusitis (1) in addition to migraine attacks.

All migraine patients had classical symptoms details of which are given in - Table 2. The duration of migraine attacks was greater than 4 hours in all patients except 13 with childhood and 5 with post head injury migraine. The common trigger factors observed among the patients were exposure to sunlight (66.7\%) and fasting for more than 6 to 8 hours $(41.3 \%)$ as shown in - Table 2.

Ninety-seven migraine patients (64.67\%) observed step-headache, whereas none of the patients with tension-type headache had this symptom during headache. Sensitivity of step-headache symptom becomes $64.67 \%$, while specificity of this symptom comes to $100 \%$. The symptom had nearly equal distribution among the two clinical subtypes (61.5\% for migraine with aura and 65.3\% for migraine without aura). Similarly post head injury and childhood migraine patients also did not show significant difference in the occurrence of this symptom. However, the symptom was more often observed in patients with perimenopausal migraine $(p=0.0368)$. The majority of patients with step-headache had this symptom during all the migraine attacks (77.32\%), while others (22.68\%) experienced it occasionally (-Table 3 ). Twenty-one out of 26 patients $(80.76 \%)$ with overlapping headaches had this symptom; 16 (76.19\%) of them observed it occasionally and 5 (23.81\%) during all attacks. In this group, this symptom was noted only during migraine attacks and not during other nonmigrainous headaches.

Among all migraineurs, this symptom was observed unilaterally in 69 (71.13\%) patients and bilaterally in 28 (28.87\%) patients. Furthermore, 22 (22.68\%) migraineurs had this symptom even during nonheadache phases of migraine attack, of which 9 had it in prodrome phase, 10 in postdrome phase, and 3 in both (-Table 3 ).

Step-headache was found to have significant association with certain other migraine features ( - Table 4 ). The patients with this symptom had significantly higher migraine attacks of pulsatile nature $(p=0.027)$. Also, their headache aggravated more often with physical activity compared to those who did not have this symptom $(p=0.015)$. However, step-headache was a symptom independent of pulsatile nature of headache and its aggravation on physical activity. This was evidenced by the fact that 3 patients (3.1\%) with this symptom experienced nonpulsatile attacks. Additionally, 23 patients (23.7\%) with this symptom had pain that did not aggravate on physical activity ( - Table 4 ). Among the migraine triggers, prolonged fasting $(74.2 \%)$ was found to have significant association with step-headache $(p=0.031$; - Table 4$)$.

\section{Discussion}

This study is based on the fact that step-headache is a symptom that is distinct from but is often confused with

Table 2 Migraine symptoms and associated features in patients enrolled in the present study

\begin{tabular}{|c|c|c|c|c|c|c|c|c|c|c|c|}
\hline \multirow{2}{*}{$\begin{array}{l}\text { Criteria of } \\
\text { sub- } \\
\text { grouping } \\
\text { migraine } \\
\text { patients }\end{array}$} & \multirow[b]{2}{*}{$\begin{array}{l}\text { Sub- } \\
\text { groups } \\
\text { of } \\
\text { migraine } \\
\text { patients, } \\
n\end{array}$} & \multirow{2}{*}{$\begin{array}{l}\text { Unilateral, } \\
n(\%)\end{array}$} & \multirow{2}{*}{$\begin{array}{l}\text { Pulsatile, } \\
n(\%)\end{array}$} & \multirow{2}{*}{$\begin{array}{l}\text { Aggravation } \\
\text { on physical } \\
\text { activity, } \\
n(\%)\end{array}$} & \multirow{2}{*}{$\begin{array}{l}\text { Photopho- } \\
\text { bia, n (\%) }\end{array}$} & \multirow{2}{*}{$\begin{array}{l}\text { Phono- } \\
\text { phobia, } \\
n(\%)\end{array}$} & \multirow{2}{*}{$\begin{array}{l}\text { Nausea, } \\
n(\%)\end{array}$} & \multirow{2}{*}{$\begin{array}{l}\text { Vomit- } \\
\text { ing, } n(\%)\end{array}$} & \multicolumn{2}{|c|}{ Triggers, $n$ (\%) } & \multirow{2}{*}{$\begin{array}{l}\text { Family } \\
\text { history, } \\
n(\%)\end{array}$} \\
\hline & & & & & & & & & $\begin{array}{l}\text { Sun- } \\
\text { light }\end{array}$ & Fasting & \\
\hline \multirow[t]{2}{*}{$\begin{array}{l}\text { Clinical } \\
\text { subtypes }\end{array}$} & $\begin{array}{l}\text { MO } \\
(124)\end{array}$ & \begin{tabular}{|l|}
86 \\
$(69.4)$
\end{tabular} & $\begin{array}{l}117 \\
(94.4)\end{array}$ & $\begin{array}{l}87 \\
(70.2)\end{array}$ & \begin{tabular}{|l|}
91 \\
$(73.4)$
\end{tabular} & $\begin{array}{l}105 \\
(84.7)\end{array}$ & \begin{tabular}{|l}
54 \\
$(43.5)$
\end{tabular} & $\begin{array}{l}50 \\
(40.3)\end{array}$ & \begin{tabular}{|l|}
83 \\
$(66.9)$
\end{tabular} & $\begin{array}{l}52 \\
(41.9)\end{array}$ & \begin{tabular}{|l}
35 \\
$(28.2)$
\end{tabular} \\
\hline & $\begin{array}{l}\text { MA } \\
(26)\end{array}$ & $\begin{array}{l}19 \\
(73.1)\end{array}$ & $\begin{array}{l}24 \\
(92.3)\end{array}$ & $\begin{array}{l}19 \\
(73.1)\end{array}$ & $\begin{array}{l}21 \\
(80.8)\end{array}$ & $\begin{array}{l}22 \\
(84.6)\end{array}$ & $\begin{array}{l}10 \\
(38.5)\end{array}$ & $\begin{array}{l}11 \\
(42.3)\end{array}$ & $\begin{array}{l}17 \\
(65.4)\end{array}$ & $\begin{array}{l}10 \\
(38.5)\end{array}$ & \begin{tabular}{|l}
8 \\
$(30.8)$
\end{tabular} \\
\hline \multirow[t]{2}{*}{ Gender } & \begin{tabular}{|l|} 
Females \\
$(123)$
\end{tabular} & \begin{tabular}{|l|}
84 \\
$(68.3)$
\end{tabular} & $\begin{array}{l}116 \\
(94.3)\end{array}$ & \begin{tabular}{|l|}
92 \\
$(74.8)$
\end{tabular} & \begin{tabular}{|l|}
94 \\
$(76.4)$
\end{tabular} & $\begin{array}{l}106 \\
(86.2)\end{array}$ & $\begin{array}{l}56 \\
(45.5)\end{array}$ & \begin{tabular}{|l|}
53 \\
$(43.1)$
\end{tabular} & \begin{tabular}{|l|}
86 \\
$(69.9)$
\end{tabular} & $\begin{array}{l}56 \\
(45.5)\end{array}$ & \begin{tabular}{|l|}
37 \\
$(30.1)$
\end{tabular} \\
\hline & \begin{tabular}{|l|} 
Males \\
$(27)$
\end{tabular} & $\begin{array}{l}21 \\
(77.8)\end{array}$ & $\begin{array}{l}25 \\
(92.6)\end{array}$ & $\begin{array}{l}14 \\
(51.9)\end{array}$ & \begin{tabular}{|l|}
18 \\
$(66.7)$
\end{tabular} & \begin{tabular}{|l|}
2 \\
$1(77.8)$
\end{tabular} & \begin{tabular}{|l|}
8 \\
$(29.6)$
\end{tabular} & \begin{tabular}{|l|}
8 \\
$(29.6)$
\end{tabular} & $\begin{array}{l}14 \\
(51.9)\end{array}$ & \begin{tabular}{|l}
6 \\
$(22.2)$
\end{tabular} & \begin{tabular}{|l}
6 \\
$(22.2)$
\end{tabular} \\
\hline \multirow{4}{*}{$\begin{array}{l}\text { Special } \\
\text { groups } \\
\text { on the } \\
\text { basis of } \\
\text { migraine } \\
\text { onset }\end{array}$} & $\begin{array}{l}\text { Ado- } \\
\text { lescent } \\
\text { onset } \\
(96)\end{array}$ & $\begin{array}{l}72 \\
(75.0)\end{array}$ & $\begin{array}{l}90 \\
(93.75)\end{array}$ & $\begin{array}{l}70 \\
(72.92)\end{array}$ & $\begin{array}{l}72 \\
(75.0)\end{array}$ & $\begin{array}{l}83 \\
(86.46)\end{array}$ & $\begin{array}{l}44 \\
(45.83)\end{array}$ & $\begin{array}{l}45 \\
(46.87)\end{array}$ & $\begin{array}{l}64 \\
(66.67)\end{array}$ & $\begin{array}{l}44 \\
(45.83)\end{array}$ & $\begin{array}{l}28 \\
(29.17)\end{array}$ \\
\hline & \begin{tabular}{|l} 
Child- \\
hood \\
$(25)$ \\
\end{tabular} & $\begin{array}{l}12 \\
(48.0)\end{array}$ & $\begin{array}{l}24 \\
(96.0)\end{array}$ & $\begin{array}{l}13 \\
(52.0)\end{array}$ & $\begin{array}{l}17 \\
(68.0)\end{array}$ & $\begin{array}{l}17 \\
(68.0)\end{array}$ & $\begin{array}{l}10 \\
(40.0)\end{array}$ & $\begin{array}{l}6 \\
(24.0)\end{array}$ & $\begin{array}{l}18 \\
(72.0)\end{array}$ & $\begin{array}{l}8 \\
(32.0)\end{array}$ & $\begin{array}{l}7 \\
(28.0)\end{array}$ \\
\hline & \begin{tabular}{|l} 
Perimen- \\
opausal \\
$(14)$
\end{tabular} & $\begin{array}{l}12 \\
(85.7)\end{array}$ & $\begin{array}{l}14 \\
(100)\end{array}$ & $\begin{array}{l}13 \\
(92.9)\end{array}$ & $\begin{array}{l}11 \\
(78.6)\end{array}$ & $\begin{array}{l}13 \\
(92.9)\end{array}$ & $\begin{array}{l}4 \\
(28.6)\end{array}$ & $\begin{array}{l}5 \\
(35.7)\end{array}$ & $\begin{array}{l}12 \\
(85.7)\end{array}$ & $\begin{array}{l}5 \\
(35.7)\end{array}$ & $\begin{array}{l}5 \\
(35.7)\end{array}$ \\
\hline & $\begin{array}{l}\text { Post head } \\
\text { injury } \\
(15)\end{array}$ & $\begin{array}{l}9 \\
(60.0)\end{array}$ & $\begin{array}{l}13 \\
(86.7)\end{array}$ & $\begin{array}{l}10 \\
(66.7)\end{array}$ & $\begin{array}{l}12 \\
(80.0)\end{array}$ & $\begin{array}{l}14 \\
(93.3)\end{array}$ & $\begin{array}{l}6 \\
(40.0)\end{array}$ & $\begin{array}{l}5 \\
(33.3)\end{array}$ & $\begin{array}{l}6 \\
(40.0)\end{array}$ & $\begin{array}{l}5 \\
(33.3)\end{array}$ & $\begin{array}{l}3 \\
(20.0)\end{array}$ \\
\hline Total & $\begin{array}{l}\text { Total } \\
(150)\end{array}$ & $\begin{array}{l}105 \\
(70.0)\end{array}$ & $\begin{array}{l}141 \\
(94.0)\end{array}$ & $\begin{array}{l}106 \\
(70.7)\end{array}$ & $\begin{array}{l}112 \\
(74.7)\end{array}$ & $\begin{array}{l}127 \\
(84.7)\end{array}$ & $\begin{array}{l}64 \\
(42.7)\end{array}$ & $\begin{array}{l}61 \\
(40.7)\end{array}$ & $\begin{array}{l}100 \\
(66.7)\end{array}$ & $\begin{array}{l}62 \\
(41.3)\end{array}$ & $\begin{array}{l}43 \\
(28.7)\end{array}$ \\
\hline
\end{tabular}

Abbreviations: MA, migraine with aura; MO, migraine without aura. 
Table 3 Characterization of step-headache symptom in migraine patients enrolled in the present study

\begin{tabular}{|c|c|c|c|c|c|c|c|c|c|}
\hline \multirow{2}{*}{$\begin{array}{l}\text { Criteria of } \\
\text { subgrouping } \\
\text { migraine } \\
\text { patients }\end{array}$} & \multirow{2}{*}{$\begin{array}{l}\text { Subgroups } \\
\text { of migraine } \\
\text { patients, } n\end{array}$} & \multirow[t]{2}{*}{$\begin{array}{l}\text { No step- } \\
\text { ache, } n(\%)\end{array}$} & \multicolumn{2}{|c|}{ Frequency, $n(\%)^{\text {a }}$} & \multicolumn{2}{|c|}{ Laterality, $n(\%)^{a}$} & \multicolumn{2}{|c|}{$\begin{array}{l}\text { Occurrence of step- } \\
\text { headache, } n(\%)^{\text {a }}\end{array}$} & \multirow{2}{*}{$\begin{array}{c}\text { Total step- } \\
\text { headache, } \\
\text { n (\%) }\end{array}$} \\
\hline & & & Always & Occasional & Unilateral & Bilateral & $\begin{array}{l}\text { Headache } \\
\text { only }\end{array}$ & $\begin{array}{l}\text { Prodrome or } \\
\text { postdrome as } \\
\text { well }\end{array}$ & \\
\hline \multirow[t]{2}{*}{ Clinical subtypes } & MO (124) & $43(34.68)$ & $62(76.54)$ & $19(23.46)$ & $59(72.84)$ & $22(27.16)$ & $63(77.78)$ & $18(22.22)$ & $81(65.32)$ \\
\hline & MA (26) & $10(38.46)$ & $13(81.25)$ & $3(18.75)$ & $10(62.50)$ & $6(37.50)$ & $12(75.00)$ & $4(25.00)$ & $16(61.54)$ \\
\hline \multirow[t]{2}{*}{ Gender } & $\begin{array}{l}\text { Females } \\
(123)\end{array}$ & $39(31.70)$ & 67(79.76) & $17(20.24)$ & $60(71.43)$ & $24(28.57)$ & $64(76.19)$ & $20(23.81)$ & $84(68.29)$ \\
\hline & Males (27) & $14(51.85)$ & $8(61.54)$ & $5(38.46)$ & $9(69.23)$ & $4(30.77)$ & $11(84.62)$ & $2(15.38)$ & $13(48.15)$ \\
\hline \multirow{4}{*}{$\begin{array}{l}\text { Special groups } \\
\text { on the basis of } \\
\text { migraine onset }\end{array}$} & $\begin{array}{l}\text { Adolescent } \\
\text { onset (96) }\end{array}$ & $34(35.42)$ & $45(72.58)$ & $17(27.42)$ & $45(72.58)$ & $17(27.42)$ & $48(77.42)$ & $14(22.58)$ & $62(64.58)$ \\
\hline & $\begin{array}{l}\text { Childhood } \\
\text { (25) }\end{array}$ & $12(48.00)$ & $9(69.23)$ & $4(30.77)$ & $8(61.54)$ & $5(38.46)$ & $11(84.61)$ & $2(15.39)$ & $13(52.00)$ \\
\hline & $\begin{array}{l}\text { Perimeno- } \\
\text { pausal (14) }\end{array}$ & $1(7.14)$ & $13(100.00)$ & $0(0.00)$ & $12(92.31)$ & 1(7.69) & $9(69.23)$ & $4(30.77)$ & $13(92.86)$ \\
\hline & $\begin{array}{l}\text { Post head } \\
\text { injury (15) }\end{array}$ & $6(40.00)$ & $8(88.89)$ & $1(11.11)$ & $4(44.44)$ & $5(55.56)$ & $7(77.78)$ & $2(22.22)$ & $9(60.00)$ \\
\hline Total & Total (150) & $53(35.33)$ & $75(77.32)$ & $22(22.68)$ & 69(71.13) & $28(28.87)$ & $75(77.32)$ & $22(22.68)$ & $97(64.67)$ \\
\hline
\end{tabular}

Abbreviations: MA, migraine with aura; MO, migraine without aura.

apercentage calculated in reference to total number of patients who experienced step-headache.

Table 4 Association of step-headache with other migraine symptoms and associated features in migraine patients enrolled in the study

\begin{tabular}{|c|c|c|c|c|c|}
\hline $\begin{array}{l}\text { Symptoms/associated features of } \\
\text { migraine }\end{array}$ & $\begin{array}{l}\text { Presence of } \\
\text { symptom/ } \\
\text { feature }\end{array}$ & $\begin{array}{l}\text { No } \\
\text { step-headache, } \\
n(\%)\end{array}$ & $\begin{array}{l}\text { Step-headache, } \\
n(\%)\end{array}$ & $p$-Value ${ }^{a}$ & OR $(95 \% \mathrm{Cl})^{\mathrm{a}}$ \\
\hline \multirow[t]{2}{*}{ Laterality } & Bilateral & $15(28.3)$ & $30(30.9)$ & \multirow[t]{2}{*}{0.899} & \multirow[t]{2}{*}{$0.947(0.408-2.198)$} \\
\hline & Unilateral & $38(71.7)$ & 67(69.1) & & \\
\hline \multirow[t]{2}{*}{ Pulsatile nature } & Non pulsatile & $6(11.3)$ & $3(3.1)$ & \multirow[t]{2}{*}{0.027} & \multirow[t]{2}{*}{$5.939(1.222-28.865)$} \\
\hline & Pulsatile & $47(88.7)$ & $94(96.9)$ & & \\
\hline \multirow[t]{2}{*}{ Photophobia } & No & $13(24.5)$ & $25(25.8)$ & \multirow[t]{2}{*}{0.173} & \multirow[t]{2}{*}{$0.473(0.161-1.387)$} \\
\hline & Yes & $40(75.5)$ & $72(74.2)$ & & \\
\hline \multirow[t]{2}{*}{ Phonophobia } & No & $10(18.9)$ & $13(13.4)$ & \multirow[t]{2}{*}{0.438} & \multirow[t]{2}{*}{$1.642(0.470-5.737)$} \\
\hline & Yes & $43(81.1)$ & $84(86.6)$ & & \\
\hline \multirow[t]{2}{*}{ Nausea } & No & $31(58.5)$ & $55(56.7)$ & \multirow[t]{2}{*}{0.632} & \multirow[t]{2}{*}{$1.211(0.553-2.653)$} \\
\hline & Yes & $22(41.5)$ & $42(43.3)$ & & \\
\hline \multirow[t]{2}{*}{ Vomiting } & No & $29(54.7)$ & 60(61.9) & \multirow[t]{2}{*}{0.139} & \multirow[t]{2}{*}{$0.548(0.246-1.216)$} \\
\hline & Yes & $24(45.3)$ & $37(38.1)$ & & \\
\hline \multirow[t]{2}{*}{ Aggravation on physical activity } & No & 21(39.6) & $23(23.7)$ & \multirow[t]{2}{*}{0.015} & \multirow[t]{2}{*}{$2.915(1.232-6.897)$} \\
\hline & Yes & $32(60.4)$ & 74(76.3) & & \\
\hline \multirow[t]{2}{*}{ Family history } & No & $37(69.8)$ & $70(72.2)$ & \multirow[t]{2}{*}{0.629} & \multirow[t]{2}{*}{$0.812(0.349-1.889)$} \\
\hline & Yes & $16(30.2)$ & $27(27.8)$ & & \\
\hline \multirow{2}{*}{$\begin{array}{l}\text { Exposure to sunlight as a trigger } \\
\text { factor }\end{array}$} & No & $20(37.7)$ & $30(30.9)$ & \multirow[t]{2}{*}{0.915} & \multirow[t]{2}{*}{$1.048(0.443-2.477)$} \\
\hline & Yes & $33(62.3)$ & 67(69.1) & & \\
\hline \multirow{2}{*}{$\begin{array}{l}\text { Fasting for } 6-8 \text { h as a trigger } \\
\text { factor }\end{array}$} & No & $37(69.8)$ & $51(52.6)$ & \multirow[t]{2}{*}{0.031} & \multirow[t]{2}{*}{$2.482(1.084-5.685)$} \\
\hline & Yes & $16(30.2)$ & $46(47.4)$ & & \\
\hline
\end{tabular}

Abbreviations: $\mathrm{Cl}$, confidence interval; OR, odds ratio

aalues in bold denote significance.

the well-known symptom of migraine, that is, throbbing headache that gets aggravated on physical exercise. Even though these two are entirely different symptoms, the distinction between them becomes difficult when the physical 
exercise involves footsteps, that is, walking, running, and climbing stairs. Occurrence of step-headache during the prodrome phase of some patients and its persistence in the nonheadache postdrome phase of some other patients indicates independent identity of this symptom. Some patients experiencing step-headache with nonpulsatile migraine attacks and with no aggravation of headache intensity on physical activity as in our study further prove our point of step-headache being a distinct symptom.

We have also tried to evaluate step-headache in various subgroups of migraine patients. No significant difference was found in the frequency of this symptom in patients with aura and those without aura. However, a weak but significant association was found $(p=0.0368)$ with perimenopausal migraine. As the number of patients in this group was small, more studies are required to confirm this observation.

In some patients with tension-type headache, hypersensitivity to external stimuli has been noted even though it is a cardinal feature of migraine. ${ }^{7}$ Though step-headache appears to be a kind of hypersensitivity to external stimulus (transmission of foot-thump to the head), we did not find this symptom in any patient with tension-type headache in isolation. Presence of step-headache only during migraine attacks in patients of overlapping headache types strengthens our view that it has close association with migraine.

Experimental studies on cats, ${ }^{8}$ rats, ${ }^{9}$ and humans suggest that the intracranial structures that subserve nociceptive function include large cerebral vessels, pial vessels, large venous sinuses, and whole of dura mater, and that the pain perception is due to a network of unmyelinated and small-diameter myelinated fibers arising from trigeminal ganglion and upper cervical dorsal roots. The fibers that arise from the trigeminal ganglion contain substance P and calcitonin gene related peptide (CGRP) that can be released by stimulation of trigeminal ganglion in human beings as well as in cats. ${ }^{10}$ The migraine attack is best explained by trigeminovascular theory, ${ }^{11}$ according to which there is sterile inflammation around the cranial structures innervated by trigeminal nerve endings. The sterile inflammation occurs secondary to release of vasoactive inflammatory neuropeptides such as CGRP, ${ }^{12}$ nitrites, vasoactive intestinal peptides (tumor necrosis

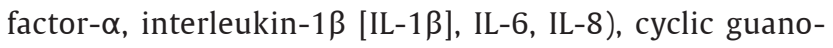
sine monophosphate, neurokinin $A,{ }^{13}$ substance $P$, neuropeptide $\mathrm{Y}^{13,14}$ and several other less well-established substances. ${ }^{15}$ Neurogenic plasma protein extravasation is observable over the inflamed dura mater after the stimulation of trigeminal ganglion. ${ }^{16}$ What triggers trigeminal neurons during migraine attack is not yet clear but it could be intrinsic brain activity in the form of cortical spreading depression. ${ }^{17}$ The ability of CGRP antagonists to treat acute migraine attacks also favors the theory of neurogenic inflammation. ${ }^{18}$ Recently, meningeal inflammation resulting in meningismus has been described in migraine, albeit in a lower percentage (12\%) than tension-type headaches. ${ }^{19}$
Hypersensitivity to various external stimuli is a wellknown feature of migraine observed during as well as in between the acute attacks. It is to the extent that sensitivity to light (photophobia) and sound (phonophobia) is considered integral part of the diagnosis. The pathophysiology of migraine and more specifically the migraine throb has not been completely understood till date. Initially proposed by Graham and Wolff after the parallel decrease in superficial temporal artery pulsations and headache on administration of ergots, the vascular theory of intracranial and extracranial vessel dilatation during the headache attacks dominated the pathophysiology of migraine till $2010 .{ }^{20}$ Some recent transcranial Doppler and magnetic resonance angiography studies also supported the view of intracranial vasodilatation ranging from 9 to $10.5 \%$ with a caveat that other theories for migraine should be looked for. ${ }^{21,22}$ Cranial vasodilation leading to enhanced blood flow in the cerebral arteries with each cardiac stroke that are then sensed by the inflamed vascular walls was the most plausible explanation for the throbbing phenomenon in migraine. ${ }^{23}$ However, a mismatch between the rate of arterial pulse and the migraine throb in a recent study ruled out the prevailing theory that the former is the only cause of the throb. ${ }^{24}$ Cortical spreading depression causing sterile perivascular inflammation and associated vascular luminal changes (vasoconstriction followed by vasodilatation) in migraine may be the basic mechanism of throb over which wide pulse pressure plays a role. Another theory of throbbing pain in migraine relates to throb-like pains sometimes observed in patients with stroke and multiple sclerosis, which are supposed to be generated by a central pacemaker. In migraine patients, this "pacemaker" could be something in the vicinity of periaqueductal gray, dorsolateral pons, thalamus, or insula as demonstrated by positron emission tomography and functional magnetic resonance imaging studies. ${ }^{25-27}$

Our results have shown that the step-headache was more common in those patients who had in addition, the symptom of throbbing headache or the aggravation of throb with physical activity. This suggests that somewhat similar mechanism may be responsible for this symptom as well. The transmission of the mechanical impact of footstep to hypersensitive cranial structures such as dural folds and dural sinuses of the brain might be sensed as painful during migraine. Our step-headache symptom can be compared more or less to "jolt accentuation" of headache, which was initially described in acute meningitis as a manifestation of meningeal irritation. ${ }^{28}$

Going by this mechanism, the step-headache should be more common in patients who experience vascular headaches and this is what was actually observed in the present study. We did not find any patient with tension-type headache experiencing this symptom. However, due to low prevalence, vascular headaches other than migraine could not be included in this study and this aspect needs further evaluation. If future studies confirm high prevalence of step-headache in migraineurs of other ethnic populations, 
this might be regarded as a cardinal symptom of migraine in addition to the existing ones.

In conclusion, the present study identifies a distinct but common symptom of migraine termed here as step-headache, which may be regarded as one of the important symptoms due to its high specificity and fairly high sensitivity.

\section{Authors' Contributions}

S.P. designed the study and wrote the manuscript. A.D. and J.G. managed the patients, collected data, and reviewed the manuscript.

\section{Funding}

None.

\section{Conflict of Interest}

None declared.

\section{Acknowledgment}

The authors acknowledge the patients for providing consent for inclusion in the study.

\section{References}

1 Woldeamanuel YW, Andreou AP, Cowan RP. Prevalence of migraine headache and its weight on neurological burden in Africa: a 43-year systematic review and meta-analysis of community-based studies. J Neurol Sci 2014;342(1-2):1-15

2 Herekar AD, Herekar AA, Ahmad A, et al. The burden of headache disorders in Pakistan: methodology of a population-based nationwide study, and questionnaire validation. J Headache Pain 2013;14:73-80

3 GBD 2016 Headache Collaborators. Global, regional, and national burden of migraine and tension-type headache, 1990-2016: a systematic analysis for the Global Burden of Disease Study 2016. Lancet Neurol 2018;17(11):954-976

4 American Association for the Study of Headache International Headache Society. Consensus statement on improving migraine management. Headache 1998;38(10):736

5 Headache Classification Committee of the International Headache Society. Classification and diagnostic criteria for headache disorders, cranial neuralgias and facial pain. Cephalalgia 1988;8(Suppl 7):1-96

6 Headache Classification Committee of the International Headache Society (IHS). The International Classification of Headache Disorders, 3rd edition (beta version). Cephalalgia.2013;33(9):629-808

7 Vingen JV, Sand T, Stovner LJ. Sensitivity to various stimuli in primary headaches: a questionnaire study. Headache 1999;39(8):552-558

8 Liu-Chen LY, Gillespie SA, Norregaard TV. Moskowitz MA. Co-localization of retrogradely transported wheat germ agglutinin and the putative neurotransmitter substance $P$ within trigeminal ganglion cells projecting to cat middle cerebral artery. J Comp Neurol 1984;225(2):187-192

9 Arbab MA, Wiklund L, Svendgaard NA. Origin and distribution of cerebral vascular innervation from superior cervical, trigeminal and spinal ganglia investigated with retrograde and anterograde WGA-HRP tracing in the rat. Neuroscience 1986;19(3):695-708

10 Goadsby PJ, Edvinsson L, Ekman R. Release of vasoactive peptides in the extracerebral circulation of humans and the cat during activation of the trigeminovascular system. Ann Neurol 1988;23(2):193-196

11 Moskowitz MA. The neurobiology of vascular head pain. Ann Neurol 1984;16(2):157-168

12 Goadsby PJ, Edvinsson L, Ekman R. Vasoactive peptide release in the extracerebral circulation of humans during migraine headache. Ann Neurol 1990;28(2):183-187

13 Sarchielli P, Alberti A, Codini M, Floridi A, Gallai V. Nitric oxide metabolites, prostaglandins and trigeminal vasoactive peptides in internal jugular vein blood during spontaneous migraine attacks. Cephalalgia 2000;20(10):907-918

14 Edvinsson L, Goadsby PJ. Neuropeptides in the cerebral circulation: relevance to headache. Cephalalgia 1995;15(4):272-276

15 Reuter U, Bolay H, Jansen-Olesen I, et al. Delayed inflammation in rat meninges: implications for migraine pathophysiology. Brain 2001;124(Pt 12):2490-2502

16 Markowitz S, Saito K, Moskowitz MA. Neurogenically mediated leakage of plasma protein occurs from blood vessels in dura mater but not brain. J Neurosci 1987;7(12):4129-4136

17 Bolay H, Reuter U, Dunn AK, Huang Z, Boas DA, Moskowitz MA. Intrinsic brain activity triggers trigeminal meningeal afferents in a migraine model. Nat Med 2002;8(2):136-142

18 Durham PL. CGRP-receptor antagonists-a fresh approach to migraine therapy? N Engl J Med 2004;350(11):1073-1075

19 Almazov I, Brand N. Meningismus is a commonly overlooked finding in tension-type headache in children and adolescents. J Child Neurol 2006;21(5):423-425

20 Graham J, Wolff $\mathrm{H}$. Mechanism of migraine headache and action of ergotamine tartrate. Arch Neurol Psychiatry 1938;39:737-763

21 Thomsen LL, Iversen HK, Olesen J. Cerebral blood flow velocities are reduced during attacks of unilateral migraine without aura. Cephalalgia 1995;15(2):109-116

22 Amin FM, Asghar MS, Hougaard A, et al. Magnetic resonance angiography of intracranial and extracranial arteries in patients with spontaneous migraine without aura: a cross-sectional study. Lancet Neurol 2013;12(5):454-461

23 Mehrotra S, Gupta S, Chan KY, et al. Current and prospective pharmacological targets in relation to antimigraine action. Naunyn Schmiedebergs Arch Pharmacol 2008;378(4):371-394

$24 \mathrm{Ahn} \mathrm{AH}$. On the temporal relationship between throbbing migraine pain and arterial pulse. Headache 2010;50(9):1507-1510

25 Buture A, Gooriah R, Nimeri R, Ahmed F. Current understanding on pain mechanism in migraine and cluster headache. Anesth Pain Med 2016;6(3):e35190

26 Craig AD. How do you feel-now? The anterior insula and human awareness. Nat Rev Neurosci 2009;10(1):59-70

27 Ahn AH. Southern Headache Society supplement: the neurobiology of throbbing pain in migraine. Headache 2012;52 (Suppl 1):12-14

28 Uchihara $T$, Tsukagoshi $H$. Jolt accentuation of headache: the most sensitive sign of CSF pleocytosis. Headache 1991;31(3):167-171 